\title{
Firm Choice Of Discount Rate Used In Valuing Pension Obligations
}

\author{
Thomas T. Amlie, Penn State Harrisburg
}

\begin{abstract}
This paper examines how the minimum liability reporting requirement for defined benefit pension plans affects the choice of actuarial assumptions. There is a long history of accounting literature which suggests that firms select accounting practices in order to artificially improve the appearance of their operations. Similarly, there is a history of research regarding the question of how firms select the actuarial assumptions used in accounting for their defined benefit pension plans. This paper makes a unique contribution to this line of research in that it explicitly examines and focuses on the effect of the "minimum liability" requirement under Statement of Financial Accounting Standard No. 87.
\end{abstract}

\section{INTRODUCTION}

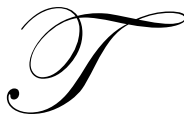

he two basic variants of pension plans are the "defined contribution plan" and the "defined benefit plan". Under a defined contribution plan, the amount which the firm contributes to the pension plan is defined by the terms of the employment contract (e.g., $5 \%$ of an employees pre-tax salary). Once that required payment has been made, the employer has no further liability. In contrast, under a defined benefit plan the retiree is guaranteed a specified (or defined) benefit after retirement. The employer is required to fund the pension plan to whatever extent is necessary to guarantee that the funds are available to pay benefits when due.

Statement of Financial Accounting Standard No. 87 "Employer Accounting for Pensions" (SFAS 87) was released in 1985. This statement established generally accepted accounting principles in accounting for defined benefit pension plans. Under SFAS 87, firms are required to make several assumptions as part of their accounting procedures.

The accounting problem in defined benefit pension plans is essentially one of estimation. Beyond the actuarial estimates regarding employee turnover and mortality, the firm must estimate the expected rate of return on pension plan assets, the expected rate of salary growth (assuming that pension benefits are based on terminal salaries), and the appropriate discount rate used to compute the present value of the pension obligation.

\section{Measuring The Disclosed Pension Liability}

The pension obligation is measured based on the present value of the expected pension benefits; hence the importance of the assumed discount rate. The two obligation measures if interest are generally the projected benefit obligation (PBO) and the accumulated benefit obligation ( $\mathrm{ABO}$ ). The projected benefit obligation is the present value of all pension benefits earned, both vested and unvested, based upon expected final salaries. The accumulated benefit obligation is the present value of all pension benefits earned, both vested and unvested, based upon current salaries.

On the firms' balance sheet, the basic evidence of the firms' pension plan is the "prepaid pension cost" (asset) or "accrued pension cost" (liability) account. This account is simply the cumulative historical total difference between the pension expense recorded and the amount contributed to the plan. If the cumulative pension expense recorded to date is greater than the cumulative funding, a liability exists. If the cumulative pension expense recorded to data is less than the cumulative funding, an asset exists. It is important to note that, due to the accounting procedures codified in SFAS 87, it is possible for a pension plan to be severely underfunded (however defined) and yet show a "prepaid pension cost" (asset) on their balance sheet. 
To address the possibility that a firm could have an underfunded pension plan and yet show a prepaid pension asset, SFAS 87 also imposes a "minimum liability" requirement on firms. The "minimum liability" is the excess of the firm's accumulated benefit obligation over its pension plan assets. If, according to this measure, the pension plan is underfunded, the firm must disclose a net pension liability at least equal to the amount of the minimum liability. If the firm already has an "accrued pension liability" at least as great as this minimum, no additional liability need be recorded. If the firm does not have an existing "accrued pension liability" of at least this magnitude they must record an "additional pension liability" in order to disclose a net liability at least equal to the required minimum. If the firm has an existing "prepaid pension asset", they are put in the unenviable position of having to record an additional liability great enough to (a) reverse the existing pension asset, and (b) create the required liability.

The illustration below illustrates how the minimum liability requirement could impact firms with different pension values:

$\begin{array}{llll} & \text { Firm A } & \text { Firm B } & \text { Firm C } \\ \text { Accumulated Benefit Obligation } & 101 & 100 & 101 \\ \text { Pension plan assets } & 100 & 100 & 100 \\ \text { Minimum liability } & 1 & 0 & 1 \\ \text { Existing liability (asset) } & 10 & (10) & (10) \\ \text { Additional liability required } & 0 & 0 & 11\end{array}$

In the case of "Firm A", a minimum liability of $\$ 1$ required. However, since they already have a $\$ 10$ "accrued pension cost" liability on their balance sheet no additional liability is required.

"Firm B" has assets exactly equal to the accumulated benefit obligation; therefore, they have no minimum liability requirement and are free to report their $\$ 10$ prepaid pension asset on the balance sheet.

"Firm C" has an accumulated benefit obligation which is \$1 greater than their pension plan assets; hence they are required to report a net liability of at least $\$ 1$. They are currently showing a $\$ 10$ prepaid pension asset, which means they will be required to book an additional $\$ 11$ liability in order to get their net liability up to the required minimum level.

Clearly, this illustration shows that firms in the position of having an existing pension asset on their balance sheet have a strong incentive to minimize their accumulated benefit obligation. Comparing firms $\mathrm{B}$ and $\mathrm{C}$ in the illustration, we see that a $\$ 1$ decrease in the projected benefit obligation can enable the firm to avoid $\$ 11$ in additional liability charges.

\section{The Effect Of The Choice Of Discount Rate And Existing Research}

The discount rate chosen by the firm can impact the firm's reported results in several ways. As was noted previously, the pension obligation is measured as a present value. The increase in the present value of the projected benefit obligation (the "interest cost" or "settlement cost") each year is one of the components of pension expense. The choice of discount rate therefore affects the annual reported pension expense, tax obligations, and funding requirements. Godwin, et al. (1996) examine this aspect of the relationship. Blankley and Swanson (1995), Newell, et al. (2002), and Asthana (1999) all examine pension assumptions with an eye towards income effects, the effect on the projected benefit obligation, and funding requirements.

The effect of discount rate choice on periodic pension expense is ultimately indeterminate. A higher discount rate leads to a lower projected benefit obligation; in the computation of periodic pension expense multiplying the higher discount rate by the lower projected benefit obligation will have a varying effect on periodic pension expense which is dependent upon the assumed pattern of future cash outflows from the pension plan.

The effect of discount rate choice on the projected benefit obligation itself is an interesting question, although for accounting purposes it is relatively unimportant in the short run. A short-run decrease in the discount rate will increase the projected benefit obligation, but this will not appear in the body of the financial statements. Instead, this 
"actuarial loss" will be deferred (off the balance sheet) and subject to amortization only if certain future criteria are met. The existing pension asset or liability reported in the body of the financial statements would be unaffected.

\section{The Current Research}

In this paper, the effect of the minimum liability reporting requirement on pension discount rate choice will be examined. According to SFAS 87, firms should select a discount rate consistent with the rate at which the "pension obligation could effectively be settled"; that is, the rate which could be earned if the firm were to defease the obligation by purchasing investment-grade fixed income securities with maturities matching the expected pension outflows. Assuming that the majority of firms with defined benefit pension plans face roughly the same time horizon for paying benefits, one would expect the selected discount rates of firms to cluster tightly around some common value each year.

In this paper, firms will be segregated based upon whether or not it appears that their choice of discount rate affected their required additional liability disclosures. To accomplish this, information of pension plan assets, the accumulated benefit obligation, the existing prepaid or accrued pension cost, and the assumed discount rate was collected for 1995 through 1997 for firms with the required data listed in the COMPUSTAT database. The sample period ended in 1997 because the number of firms disclosing accumulated benefit obligation information dropped off precipitously after 1997. Firms which had multiple pension plans had their assets and obligations across plans merged into single measures.

First, the firms reported "additional liability" position is determined based upon their reported accumulated benefit obligation, their pension plan assets, and their existing prepaid/accrued pension cost amounts. Firms with an additional liability requirement were coded as "1", while those without an additional liability requirement were coded as " 0 ".

Next, the firms' reported accumulated benefit obligation measures were restated on a pro-forma basis to reflect what the obligation would have been had the firm used the average discount rate for that sample year. Clearly, this is the most difficult aspect of the work to defend. Unfortunately, there is no publicly available information which would allow us to infer the effect of discount rate changes on a firm's accumulated benefit obligation. Based on an examination of a sample of firms' $10-\mathrm{K}$ reports, it appears that a one-percentage-point change in the discount rate yields a change in the firms' projected benefit obligation in the range of $5 \%$ to $8 \%$. Given that the projected benefit obligations cash flows are more heavily weighted further into the future than are the accumulated benefit obligations' cash flows, the accumulated benefit obligation would be less sensitive to changes in the discount rate. The conservative estimation was made that a one-percentage-point change in the discount rate would yield a $1 \%$ change in the accumulated benefit obligation. Under this construct, if a firm used a $7 \%$ discount rate and reported an accumulated benefit obligation of $\$ 100$, while the average across all firms was $6 \%$, that firm's accumulated benefit obligation would be increased by $1 \%$ from 100 to 101 . If the firm had used a $6.5 \%$ discount rate the accumulated benefit obligation would be revised upwards from 100 to 100.5 .

After recalculating the firms' accumulated benefit obligation measures, the firms were once again coded as "1" for those firms requiring an additional liability accrual, and "0" for those not requiring an additional liability accrual.

Finally, firms were coded based on whether or not they moved from the non-additional-liability group based on their reported discount rate to the additional-liability group based on use of the sample average discount rate. The coding was as follows:

1: $\quad$ Firms who move from a non-additional-liability position based on their selected discount rate to an additional liability position based on the across-sample average rate

0: $\quad$ Otherwise 
Stated in the null form, the hypothesis would be that firms in "Group 1" did not have significantly higher discount rates than those in "Group 0 ". If it is found that the discount rates in "Group 1" firms are significantly higher than those in "Group 0" it would suggest that these firms are selecting these higher discount rates in order to avoid the accrual of the additional liability measure. Essentially it is a question of whether firms which can benefit from a higher discount rate are in fact selecting a higher discount rate.

\section{Results - 1995 Sample}

Based on the data available in the COMPUSTAT data files for 1995, there were 1,090 firms with the required data available. Of this group, only $76(7 \%)$ were in a position to require an additional liability accrual. The average discount rate for the period was $7.418 \%$, with individual firms ranging from a low of $4 \%$ to a high of $11 \%$.

After adjusting the accumulated benefit obligations as discussed above, the number of firms which moved from a non-additional-liability position to an additional-liability position was 234 , or $23 \%$ of those who had previously not needed to report an additional liability. The average discount rate for the two groups was compared using a simple t-test, with the following results:

\begin{tabular}{lcc}
\hline & Group 0 & Group 1 \\
\hline Mean & 7.334001168 & 7.723932 \\
Variance & 0.204658563 & 0.158738 \\
Observations & 856 & 234 \\
Hypothesized Mean Difference & 0 & \\
t Statistic & 12.87344358 & \\
P(T<=t) two-tail & $4.14005 \mathrm{E}-32$ & \\
t Critical two-tail & 1.965736374 & \\
\hline
\end{tabular}

Clearly, the firms in "Group 1" selected a substantially higher discount rate. This suggests that firms which would have normally found themselves in a position of needing to accrue an additional liability were able to avoid that position by selecting an unusually high discount rate.

\section{Results - 1996 Sample}

Based on the data available in the COMPUSTAT data files for 1996, there were 1,129 firms with the required data available. Of this group, only $58(5 \%)$ were in a position to require an additional liability accrual. The average discount rate for the period was $7.559 \%$, with individual firms ranging from a low of $4.5 \%$ to a high of $10 \%$.

After adjusting the accumulated benefit obligations as discussed above, the number of firms which moved from a non-additional-liability position to an additional-liability position was 210 , or $20 \%$ of the firms which were previously in the no-additional-liability category. The average discount rate for the two groups was compared using a simple t-test, with the following results:

\begin{tabular}{lcc}
\hline & Group 0 & Group 1 \\
\hline Mean & 7.4835691 & 7.8905238 \\
Variance & 0.1538329 & 0.0372567 \\
Observations & 919 & 210 \\
Hypothesized Mean Difference & 0 & \\
$\mathrm{t}$ statistic & -21.91592 & \\
$\mathrm{P}(\mathrm{T}<\mathrm{t})$ two-tail & $2.638 \mathrm{E}-80$ & \\
$\mathrm{t}$ Critical two-tail & 1.9635854 & \\
\hline
\end{tabular}




\section{Results - 1997 Sample}

Based on the data available in the COMPUSTAT data files for 1997, there were 1,128 firms with the required data available. Of this group, only $44(4 \%)$ were in a position to require an additional liability accrual. The average discount rate for the period was $7.277 \%$, with individual firms ranging from a low of $4 \%$ to a high of $12 \%$.

After adjusting the accumulated benefit obligations as discussed above, the number of firms which moved from a non-additional-liability position to an additional-liability position was 210 , or $19 \%$ of the firms which were previously in the no-additional-liability category. The average discount rate for the two groups was compared using a simple t-test, with the following results:

\begin{tabular}{lcc}
\hline & Group 0 & Group 1 \\
\hline Mean & 7.194199 & 7.641429 \\
Variance & 0.163961 & 0.061133 \\
Observations & 918 & 210 \\
Hypothesized Mean Difference & 0 & \\
Degrees of freedom & 501 & \\
$\mathrm{t}$ statistic & -20.6354 & \\
$\mathrm{P}(\mathrm{T}<=\mathrm{t})$ one-tail & $3.13 \mathrm{E}-69$ & \\
$\mathrm{t}$ Critical one-tail & 1.6479 & \\
$\mathrm{P}(\mathrm{T}<=\mathrm{t})$ two-tail & $6.26 \mathrm{E}-69$ & \\
\hline
\end{tabular}

\section{CONCLUDING REMARKS}

The evidence presented here clearly suggests that there is a strong association between the discount rates firms use to compute their pension obligations and their potential minimum liability accrual concerns. The small number of firms in a reported additional liability position, compared to the large number in such a position based on adjusted pro-forma measures, suggests that firms manage these assumptions to avoid being placed in the position of requiring an additional liability accrual. Firms which would be forced to accrue an additional liability if market discount rates were used use substantially higher discount rates and hence avoid the need to accrue the additional liability.

The greatest methodological weakness in this paper is the reliance on a pro-forma measure of the "true" accumulated benefit obligation. Unfortunately, barring access to the firms actuarial data the true cash flow patterns, and the resulting sensitivity to interest rate adjustments, will never be known. The author believes that the use of an extremely conservative adjustment factor (1\% change in accumulated benefit obligation for every $1 \%$ change in the discount rate) mitigates against any overwhelming criticism from this quarter.

A second weakness involves the use of COMPUSTAT data itself. The pension data, which is reported in footnotes to the firms' financial statements, is apparently not treated with the same care by Standard and Poor's as is data from the body of the financial statements, and is prone to contain erroneous data. The author has an on-going data collection project wherein this pension data is being hand-collected from firms' $10-\mathrm{K}$ reports.

\section{REFERENCES}

1. Asthana, Sharad. Determinants of Funding Strategies and Actuarial Choices for Defined-Benefit Pension Plans. Contemporary Accounting Research, spring 1999, volume 16, issue 1, pp. 39 - 74.

2. Blankley, Alan I. and Edward P. Swanson A Longitudinal Study of SFAS 87 Pension Rate Assumptions. Accounting Horizons, December 1995, Volume 9, Issue 4, pp. 1 - 21. 
3. Godwin, Joseph H., Stephen R. Goldberg, and Jon E. Duchac, An Empirical Analysis of Factors Associated with Changes in Pension-Plan Interest-Rate Assumptions. Journal of Accounting, Auditing, and Finance, Spring 1996. Vol. 11, Issue. 2; p. $305-322$.

4. Newell, Gale E. Jerry G. Kreuze, and David Hurtt. Corporate Pension Plans: How Consistent are the Assumptions in Determining Pension Funding Status. Mid-American Journal of Business, fall, 2002 , v17 no 2, pp $23-30$.

\section{NOTES}

